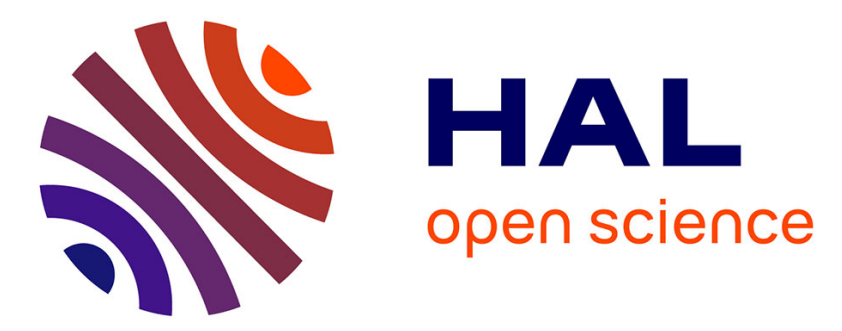

\title{
Environmental genotoxicity and cytotoxicity in the offshore zones of the Baltic and North Seas
}

Aleksandras Rybakovas, Janina Baršienè, Thomas Lang

\section{To cite this version:}

Aleksandras Rybakovas, Janina Baršienė, Thomas Lang. Environmental genotoxicity and cytotoxicity in the offshore zones of the Baltic and North Seas. Marine Environmental Research, 2009, 68 (5), pp.246. 10.1016/j.marenvres.2009.06.014 . hal-00520357

\section{HAL Id: hal-00520357 https://hal.science/hal-00520357}

Submitted on 23 Sep 2010

HAL is a multi-disciplinary open access archive for the deposit and dissemination of scientific research documents, whether they are published or not. The documents may come from teaching and research institutions in France or abroad, or from public or private research centers.
L'archive ouverte pluridisciplinaire HAL, est destinée au dépôt et à la diffusion de documents scientifiques de niveau recherche, publiés ou non, émanant des établissements d'enseignement et de recherche français ou étrangers, des laboratoires publics ou privés. 


\section{Accepted Manuscript}

Environmental genotoxicity and cytotoxicity in the offshore zones of the Baltic and North Seas

Aleksandras Rybakovas, Janina Baršienė, Thomas Lang

PII:

S0141-1136(09)00084-1

DOI:

10.1016/j.marenvres.2009.06.014

Reference:

MERE 3353

To appear in:

Marine Environmental Research

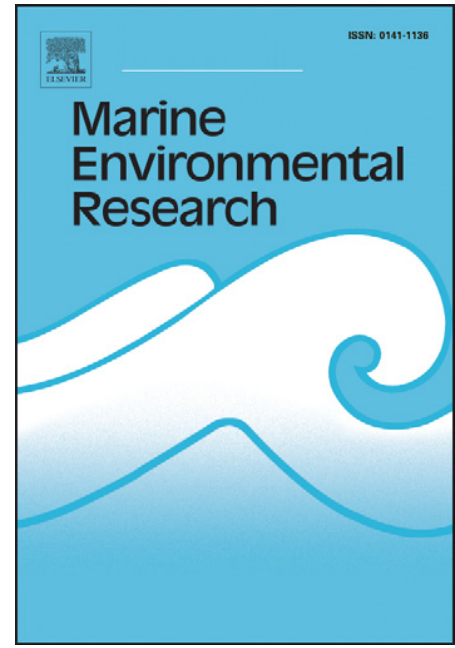

Received Date: $\quad 2$ October 2008

Revised Date: $\quad 5$ June 2009

Accepted Date: $\quad 15$ June 2009

Please cite this article as: Rybakovas, A., Baršienè, J., Lang, T., Environmental genotoxicity and cytotoxicity in the offshore zones of the Baltic and North Seas, Marine Environmental Research (2009), doi: 10.1016/j.marenvres. 2009.06.014

This is a PDF file of an unedited manuscript that has been accepted for publication. As a service to our customers we are providing this early version of the manuscript. The manuscript will undergo copyediting, typesetting, and review of the resulting proof before it is published in its final form. Please note that during the production process errors may be discovered which could affect the content, and all legal disclaimers that apply to the journal pertain. 


\title{
Environmental genotoxicity and cytotoxicity in the offshore zones of the Baltic and North Seas
}

\author{
Aleksandras Rybakovas ${ }^{\mathrm{a}}$, Janina Baršien ${ }^{\mathrm{a}}$, Thomas Lang ${ }^{\mathrm{b}}$ \\ anstitute of Ecology of Vilnius University, Akademijos 2, 08412 Vilnius, Lithuania \\ ${ }^{\mathrm{b}}$ Federal Research Centre for Fisheries, Institute of Fishery Ecology, Deichstrasse 12, 27472 \\ Cuxhaven, Germany
}

\section{Corresponding author - Aleksandras Rybakovas}

Tel: +37061462900

Fax: +370 52729257

Email: arybakovas@ekoi.lt

Institute of Ecology of Vilnius University

Akademijos 2

08412, Vilnius

Lithuania

\section{Abstract}

Micronuclei (MN), nuclear buds (NB) and fragmented-apoptotic cells (FA) were analyzed in mature peripheral blood and immature cephalic kidney erythrocytes of flounder (Platichthys flesus), dab (Limanda limanda) and cod (Gadus morhua) from 12 offshore sites in the Baltic Sea (479 specimens) and 11 sites in the North Sea (291 specimens), which were collected during three research vessel cruises in December 2002, 2003 and in September 2004. The highest levels of environmental genotoxicity (frequencies of $\mathrm{MN}$ up to $0.5 \%$, $\mathrm{NB}-$ up to $0.75 \%$ ) and cytotoxicity (FA - up to $0.53 \%$ ) were observed in flatfishes from areas close to oil and gas platforms in the North Sea and in zones related to the extensive shipping and potentially influenced by contamination from large European Rivers (Elbe, Vistula, Oder). In dab from the offshore zones of the North Sea, the levels of nuclear abnormalities were higher as compared to those in dab from the Baltic Sea. Responses in immature kidney erythrocytes were higher than in mature erythrocytes from peripheral blood. MN frequency lower than $0.05 \%$ (the Baltic Sea) and lower than $0.1 \%$ (the North Sea) could be suspected as a reference level in the peripheral blood erythrocytes of flatfish.

Keywords: Genotoxicity; Cytotoxicity; Micronuclei; Nuclear abnormalities; Erythrocytes; Baltic Sea; North Sea. 


\section{Introduction}

Surrounded by European countries, the Baltic and the North Seas are constantly exposed to anthropogenic pressure. With pollution from land-based discharges, coastal industries, municipal outflows, agricultural activities, oil and gas industry (drilling and transportation) and transport activities, thousands of chemicals are entering the marine environment. A large proportion of these compounds are potentially toxic, genotoxic and carcinogenic to aquatic organisms (Jha, 2004, 2008). The interaction of genotoxic contaminants with DNA causes various genetic disturbances, which often are irreversible and can be transmitted to the next generations (Depledge and Fossi, 1994; Dixon et al., 1999; Jha, 2004). The analysis of environmental genotoxicity provides early warning signs of adverse long-term effects of contamination. A number of biomarkers have been applied for assessment of environmental genotoxicity and the micronuclei (MN) test, as one of the most popular approaches, has served as an index of cytogenetic damage for more than 30 years (Boller and Schmid, 1970; Schmid, 1975; Heddle et al., 1991). The assay is well elaborated and allows to evaluate the genotoxicity of compounds at low concentrations and to assess doseresponse relationships of both DNA reactive and non-DNA reactive genotoxins (e.g. aneugens) (Al-Sabti et al., 1994; Palhares and Grisolia, 2002; Pacheco and Santos, 2002; Gravato and Santos, 2002, 2003; Rodriguez-Cea et al., 2003; Teles et al., 2003) Micronuclei arise from chromosome fragments or whole chromosomes that lag at cell division due to lack of centromere, damage in centromere region, or defect in cytokinesis (Fenech, 2000). MN are small, secondary structures of chromatin, are surrounded by membranes, located in the cytoplasm and have no detectable link to the cell nucleus (Boller and Schmid, 1970; Heddle, 1973; Heddle et al., 1991; MacGregor, 1991).

The MN test has successfully been applied in fish for the assessment of marine genotoxicity in situ (Hayashi et al., 1998; Al-Sabti and Metcalfe, 1995; Bolognesi et al., 1996, 2006a; Pietrapiana et al., 2002; Çavaş and Ergene-Gözükara, 2003, 2005a; Baršienė et al., 2004, 2005, 2006a, 2006b, 2006c; Köhler and Ellesat, 2008). In recent years, growing attention has been paid to nuclear abnormalities other than $\mathrm{MN}$ and it was demonstrated that these nuclear abnormalities can serve as an index of genotoxic and cytotoxic damage (Carrasco et al., 1990; Dolcetti and Venier, 2002; Ateeq et al., 2002; Pacheco and Santos, 2002; Gravato and Santos, 2002, 2003; Çavaş and Ergene-Gözükara, 2003, 2005b; Frenzilli et al, 2004, Bolognesi et al., 2006b, Baršiené et al., 2006a, 2006c; Baršienè and Andreikènaitè, 2007). Nuclear buds are morphologically similar to micronuclei with the exception that they are joined to the nucleus by a thin nucleoplasmic connection. It is suggested that nuclear buds arise from the elimination of amplified DNA (Miele et al., 1989; Shimizu et al., 1998, 2000) and possibly of DNA-repair complexes (Haaf et al., 1999). Studies performed by Lindberg and colleagues (2007) reveal that in normal and folate-deprived human lymphocytes the majority of nuclear buds originate from interstitial acentric chromosomal fragments, some of them are formed from terminal chromosome fragments or whole chromosomes, possibly representing nuclear membrane entrapment of DNA, that has been left in cytoplasm after nuclear division or excess DNA. Though, most of the nuclear buds have different origin than micronuclei, studies in human tumor cells have indicated, that in the S-phase of the cell cycle amplified chromosomal or double minute DNA may form buds, later disintegrate from the nucleus and become a micronucleus (Pedeutour et al., 1994, Shimizu et al., 1998, 2000, Yankiwski et al., 2000). Fragmentation of cells and apoptosis can be provoked by a variety of factors, including those with genotoxic potential (Steinert, 1996; Steinert et al., 1998; Mičić et al., 2001; Baršienè et al., 2005; 2006a, 2006d), or directly associated to cytotoxic events (Bolognesi et al., 2006b). Data on other nuclear abnormalities presents a wider view on cellular processes following the exposure and permits the measurement of important complementary genotoxicity and cytotoxicity events. 
In the last decades, environmental genotoxicity in coastal areas of the Baltic and the North Seas was assessed in the number of studies (Al-Sabti and Hardig, 1990; Bresler et al., 1999; Baršienė et al., 2000, 2006b, Thiriot-Quiévreux and Wolowicz, 2001; Bombail et al., 2001; Frenzilli et al., 2004; Schiedek et al., 2006; Kopecka et al., 2006; Broeg and Lehtonen, 2006; Lehtonen et al., 2006; Stachnik and Wolowicz, 2007; Köhler and Ellesat, 2008). However, there is a lack of information on genotoxic and cytotoxic effects in the offshore areas of the Baltic and the North Seas. The aim of the current study was to evaluate genotoxic and cytotoxic effects of environmental pollution in selected offshore sites of the Baltic and the North Seas. The assessment of $\mathrm{MN}$ and nuclear buds (genotoxicity endpoints) and fragmented-apoptotic cells (cytotoxicity endpoint) was performed in mature peripheral blood erythrocytes of the flatfish species flounder (Platichthys flesus) and dab (Limanda limanda) as well as in Atlantic cod (Gadus morhua). Specific inter-tissue differences in induction of MN and the other nuclear abnormalities were observed during in vivo studies of the genotoxicity and cytotoxicity of endocrine disruptors and flame retardants (Baršienè et al., 2005) as well as crude oil and nonylphenol (Baršienè et al., 2006a) carried with Atlantic cod and turbot (Scophthalmus maximus). In order to assess tissues specific peculiarities of genotoxic and cytotoxic effects in offshore zones of the Baltic and the North Seas, in samples collected in September 2004 immature cephalic kidney erythrocytes were additionally analyzed.

\section{Material and methods}

\subsection{Sampling}

Samples were collected during three cruises with the German RV Walther Herwig III to the Baltic and North Seas, organized by the the Institute of Fishery Ecology of the Federal Research Centre for Fishery. In December 2002, 2003 and September 2004, flounder (Platichthys flesus), dab (Limanda limanda) and Atlantic cod (Gadus morhua) were collected in 12 sampling areas in the Baltic Sea and 11 areas in the North Sea (Fig. 1).

Brief description and details on geographical coordinates, sampling depth, water temperature and salinity of the sampling areas are presented in Table 1 and Table 2. Data about studied organisms and number of specimens collected during each cruise in the different sampling areas are presented in Table 3. Fishes were collected by bottom trawling; using a $180 \mathrm{ft}$ (1 foot $=0.3048 \mathrm{~m})$ trawls, with a towing time of $1 \mathrm{~h}$. Only live specimens, all strictly of the same size (total length (L) of flatfishes: 20-24 cm; cods: 28-32 cm) were processed for analysis.

\subsection{Sample preparation and analysis}

A drop of blood from caudal vessels was directly smeared on glass slides and air-dried. Smears of immature erythrocytes were prepared directly; using a small piece of cephalic kidney gently dragged along a clean slide and allowed to dry for 1-2 h (Baršienè, 1980). Smears were fixed in methanol for $10 \mathrm{~min}$ and were stained with 5\% Giemsa solution for 8 min (Baršienè et al., 2004). The frequency of micronuclei, nuclear buds and fragmented-apoptotic cells was evaluated by scoring at $1000 \times$ magnification, using an Olympus BX51 microscope. A total of 5000 erythrocytes from peripheral blood were examined for each fish specimen. In flatfishes, which were sampled in September 2004, additionally 5000 immature erythrocytes from the cephalic kidney were analyzed.

Micronuclei were identified according to the following criteria: round- or ovoid-shaped nonrefractory particles in the cytoplasm, with optical features, structure and color resembling those of 
the nucleus, clearly detached from the main nucleus and with a diameter of $1 / 3-1 / 20$ of the main nucleus (Fig. 2).

Other nuclear abnormalities, nuclear buds (NB) and fragmented-apoptotic cells (FA), were identified using criteria described by Fenech and co-authors (2003). Nuclear buds were characterized as extruded nuclear material that appears like a micronucleus with a narrow nucleoplasmic bridge to the main nucleus. Fragmented-apoptotic cells in early stages were identified by the presence of chromatin condensation within the nucleus and intact cytoplasmic and nuclear boundaries, late apoptotic cells exhibit nuclear fragmentation into smaller nuclear bodies within an intact cytoplasm/cytoplasmic membrane. Staining intensity in the nucleus, nuclear fragments and cytoplasm of apoptotic cells was usually greater than in viable cells (Fig. 2).

Statistical analysis was performed by using PRISM, STATISTICA 6.0 packages. Mean and standard errors were calculated for each study group. The frequency of nuclear abnormalities was evaluated as a number of injures per 1000 cells (\%o). Data was analyzed with one-way ANOVA, whereas differences between groups and between tissues were assessed with the non-parametrical Mann-Whitney U test.

\section{Results}

\subsection{Baltic Sea}

In December 2002, the highest levels of MN (0.25\%) were recorded in the Baltic Sea flounder from the offshore zones of the Mecklenburg Bight (BEEP5) (Fig. 3). In flounder from area B01, MN frequencies were lowest $(0.05 \%)$, but the levels of NB (0.75\%) and FA $(0.53 \%$ ) erythrocytes were highest and were 5-7.5 times higher than in flounder from the other sampling areas of the Baltic Sea. ANOVA analysis revealed significant differences between areas (MN$\mathrm{P}<0.0001, \mathrm{~F}=5.95 ; \mathrm{FA}-\mathrm{P}<0.0001, \mathrm{~F}=19.17 ; \mathrm{NB}-\mathrm{P}<0.0001, \mathrm{~F}=22.78)$. The lowest level of cytogenetic damage was observed in flounder from the offshore area of Lithuania (BEEP3) (MN $0.06 \%$, NB $-0.01 \%$, FA cells $-0.02 \%$ ).

In December 2003, the highest levels of all studied parameters were observed in erythrocytes of flounder from area BEEP4 (MN - $0.09 \%, \mathrm{NB}-0.11 \%$ and FA $-0.11 \%$ ), which is located close to the Gulf of Gdansk and is potentially influenced by water masses of the second-largest river in the Baltic Sea, the Vistula (Fig. 3). A comparatively high level of environmental genotoxicity was also observed in flounders from area B10 influenced by the Oder River (MN $0.11 \%$ and NB - $0.22 \%$ ) and, like in December 2002, in flounder from areas BEEP5 (MN - 0.08 $\%, \mathrm{NB}-0.25 \%$ ) and $\mathrm{B} 01(\mathrm{MN}-0.06 \%, \mathrm{NB}-0.24 \%$ ), although frequencies of fragmented apoptotic cells were comparatively low. The lowest frequencies of $\mathrm{MN}$ and other nuclear abnormalities were recorded in flatfishes from area B11 (MN $-0.05 \%$, FA $-0.01 \%$ and NB $0.04 \%$ ). Dispersive ANOVA analysis displayed that only differences of the frequencies of NB assessed in different areas were significant $(\mathrm{P}<0.05, \mathrm{~F}=2.07)$. A comparison of genotoxic and cytotoxic effects observed in flounder in 2002 and 2003 revealed the stability of the studied parameters. The only exception was area B01, where an enormous increase in $\mathrm{MN}$ and a decrease in NB were observed in 2003.

Comparative analysis in mature and immature erythrocytes in flounder, collected in the Baltic Sea in September 2004, revealed that the frequency of micronuclei and fragmented-apoptotic cells are generally higher in immature erythrocytes from cephalic kidney (Fig. 4), although differences of $\mathrm{MN}, \mathrm{NB}$ and FA were not statistically significant. The frequency of $\mathrm{MN}$ in flounders from four different offshore areas in the Baltic Sea ranged from $0.33 \%$ to $0.19 \%$ in peripheral blood erythrocytes and from $0.3 \%$ to $0.2 \%$ in erythrocytes from cephalic kidney. 
In areas B01 and B11, flounders were collected in December 2003 and September 2004. Generally, higher frequencies of $\mathrm{MN}, \mathrm{NB}$ and FA cells were recorded in flounders collected in September (Fig. 3). However, significant $(\mathrm{P}<0.05)$ seasonal differences were observed only in fishes from area B11.

Levels of genotoxic and cytotoxic effects were also evaluated in erythrocytes of dabs from the Baltic Sea areas B01 and BEEP5. The highest values of studied parameters were observed in December 2003 in dabs from B01 area (MN - $0.13 \%$, NB - $0.43 \%$ and FA - $0.03 \%$ ), the lowest $(\mathrm{MN}-0.15 \%, \mathrm{NB}-0.18 \%$ and $\mathrm{FA}-0.03 \%$ ) - in dabs from the area BEEP5. In dab from the offshore zones of the Baltic Sea, the levels of nuclear abnormalities were lower as compared to those in dabs from the North Sea (Fig. 5).

\subsection{North Sea}

In dab from the North Sea offshore areas comparatively close to the cities of Edinburgh (N06) and Hamburg (N01), the highest frequencies of erythrocytes with $\mathrm{MN}(0.19 \%$ and $0.2 \%)$ and NB $(0.78 \%$ and $0.68 \%$ ) were observed in December 2003. In dab from oil field area P01, the level of $\mathrm{MN}$ was lowest $(0.02 \%$ and $0.06 \%$ ), but frequency of FA in erythrocytes was considerably high $(0.26 \%$ and $0.57 \%$ ) and significantly (P varied from 0.0054 to 0.0074$)$ differed from FA frequencies recorded in the other study areas (Fig. 5). Analysis of $\mathrm{MN}$ frequencies in dab from two stations within area P01 (P01/51 and P01/52) showed responses related to the distance of the station from the oil platforms. The frequency of $\mathrm{MN}$ was three times higher and that of FA was two times higher in the fish collected closely to the oil platforms (P01/52), than in those from the more distant location (P01/51).

In September 2004, the highest level of genotoxic and cytotoxic effects was observed in peripheral blood erythrocytes of dabs collected in the North Sea areas affected by pollution from gas and oil extraction: N04 (MN $-0.44 \%$, NB $-0.38 \%$ and FA $-0.44 \%$ ) and P01 (MN -0.23 $\%$, NB $-0.48 \%$ and FA - $0.37 \%$ ). Like in the year 2003, a distance-dependent response was observed in fish from study areas P01 and P02 (Fig. 5). A seven times higher MN frequency and a two times higher FA frequency were found in dab from the station closest to the oil platforms. Comparatively high frequencies of abnormalities were also observed in fish from the offshore area JMP, potentially affected by the pollution from Elbe River (MN $-0.21 \%$, NB $-0.28 \%$ and FA $0.35 \%$ ). The lowest level of environmental genotoxicity and cytotoxicity in the North Sea was detected in area N06 (MN $-0.12 \%$ and NB $-0.23 \%$ ).

Inter-tissue analysis of MN, NB and FA revealed similar pattern of responses in the different study areas (Fig. 6). Higher levels of the studied parameters were observed in dab immature cephalic kidney erythrocytes than in mature blood erythrocytes. Statistically significant inter-tissue differences were observed in levels of FA cells in dabs from areas JMP (Mann-Whitney U test, $\mathrm{P}=0.0167)$ and $\mathrm{N} 22(\mathrm{P}=0.0371)$.

Analysis of gender-specific responses showed in general a higher frequency of MN, NB and FA in flatfish female erythrocytes compared to responses in males. Statistically significant differences were observed in $\mathrm{MN}$ frequencies in mature erythrocytes of dab from area N06 $(\mathrm{P}=0.0433), \mathrm{NB}$ frequencies in immature erythrocytes of fish from areas $\mathrm{N} 04(\mathrm{P}=0.0057), \mathrm{N} 06$ $(\mathrm{P}=0.0204)$ and $\mathrm{N} 11(\mathrm{P}=0.0101)$ and FA frequencies in immature erythrocytes of dabs from areas $\mathrm{N} 03(0.0281)$ and $\mathrm{N} 22(\mathrm{P}=0.0281)$.

Studies of nuclear abnormalities in Atlantic cod (G. morhua) in December 2003 and September 2004 revealed seasonal differences. Frequencies of nuclear abnormalities in December 
2003 were very low, while in September of the next year, the levels of the damage were 3-10 times higher (Fig. 7).

\section{Discussion}

In the offshore zones of the Baltic Sea, the highest levels of environmental genotoxicity and cytotoxicity were observed in extensive ship traffic zones, as well as in the areas potentially influenced by the rivers Vistula and Oder, while the lowest responses were determined in Baltic areas far away from potential sources of pollution.

According to HELCOM (2003), the intense shipping in the Baltic Sea accounts for approximately $15 \%$ of all maritime traffic in the world. Every year, approximately 37000 ships with 48 millions tons of cargo are passing through the Kiel (Kaiser Wilhelm) Canal between the Baltic and the North Sea. It is known that such areas with extensive navigation are polluted e.g. by oil products, metals and organotin compounds. Water concentrations of TBT in such areas can reach $100 \mathrm{ng} \mathrm{l}^{-1}$ while, in other offshore areas, its concentration can be less than $1 \mathrm{ng} \mathrm{l}^{-1}$ (OSPAR, 2000). Several studies have demonstrated that TBT can induce shell malformations in oysters, imposex in gastropods, reduced resistance to infection in flatfish and that it is genotoxic and cytotoxic to molluscs and fish (Mičić et al., 2001; Ruedel et al., 2003; HELCOM, 2003; Ferraro et al., 2004; Hagger et al., 2005). Despite the ban of it use, studies performed on herring, flounder, pikeperch, sea birds, and blue mussels demonstrated that TBT is still present in the Baltic Sea water organisms at elevated concentrations (Kannan et al., 1999; Albalat et al., 2002; Strand and Jacobsen, 2005).

Studies performed by Schulz and Emeis (2000) and Witt et al. (2001) demonstrated that rivers such as the Vistula and Oder have an influence not only on coastal areas, but also on offshore zones of the Baltic Sea with respect to contamination. In the Baltic Sea, higher molecular weight PAHs are being intensively accumulated in a fluffy layer of the bottom sediments of the Arkona and Gotland Basins. Analysis of such PAHs demonstrated that these compounds are originating in the basin of the Oder and Vistula Rivers. Along a transport gradient from the Oder Lagoon to the Arkona Basin, concentrations of higher molecular weight PAHs ranged between 322 and $1700 \mathrm{ng}$ $\mathrm{g}^{-1}$.d.w. Among the individual PAH compounds, a clear dominance of fluoranthene, pyrene and the four- to six-ring aromatics was observed (Witt et al., 2001). Seasonal changes of PAH concentrations were determined by Witt (2002), the highest PAH concentrations were measured in February likely due to higher inputs from combustion sources and slower degradation.

Studies of Atlantic cods from the off shore areas of the Baltic Sea performed in December 2001 by Schnell and colleagues (2008) reveal spatial differences in biomarker responses as well as in contaminant loads. Highest AChE values and PCB concentrations (eight congeners) were measured in cods from Kiel Bight. On the other hand, in those cods lowest amount of DNA adducts as well as concentration of DDT compounds (DDT, DDE, and DDD) and HCH content was observed. Studies of cods from off shore areas of the Gdansk Bay reveal markedly increased contamination of the area, where highest concentrations of PAH metabolites (1-OH pyrene), DDT compounds and $\mathrm{HCH}$ were found. Increased level of environmental genotoxicity in off shore areas of the Gdansk Bay was confirmed by analysis of DNA adducts (Schnell et al., 2008). In the sediments and water organisms of the Gulf of Gdansk, high concentrations of aromatic amines, phenols, heavy metals $(\mathrm{Cd}, \mathrm{Cr}, \mathrm{Se}, \mathrm{As}, \mathrm{Ni}, \mathrm{Pb}, \mathrm{Mn}, \mathrm{Cu}, \mathrm{Fe})$, detergents, organotins, PCBs, pesticides, insecticides like DDT and cyclodienes have been found (Falandysz et al., 2002; Galassi et al., 2008). Long-time exposure of water organisms to PCBs induces neoplastic changes and liver 
cancer (Silberhorn et al., 1990), PCBs are genotoxic to water organisms (Rosas et al., 1984; Akcha et al., 2003).

Field studies in the framework of the EU-funded BEEP project (Biological Effects of Environmental Pollution in Marine Coastal Ecosystems, 2001-2004) demonstrated biological impacts of pollution in different coastal areas of the Baltic Sea and the North Sea (Lehtonen et al., 2006; Baršienè et al., 2004, 2006b, 2006d; Lang et al., 2006; Schiedek et al., 2006; Kopecka et al., 2006). Highest genotoxicity levels were observed in fish and mussels from the Gulf of Gdansk. Comparatively high levels of the responses have been detected in eelpouts and mussels collected in 2001 from Wismar Bay and from the Lithuanian coast (Baršienè et al., 2004, 2006b, 2006d; Schiedek et al., 2006; Kopecka et al., 2006).

In the North Sea, increased levels of genotoxic and cytotoxic effects were recorded in areas close to oil and gas platforms, zones with extensive navigation and areas which are potentially impacted by contamination from the Elbe River. Genotoxicity and cytotoxicity of oil, alkylphenols, nonylphenols, PAHs and their mixtures have been shown by studying in vivo blue mussels, Atlantic cod and turbot from the North Sea (Baršienè et al., 2005, 2006a; Bolognesi et al., 2006b; Baršiene் and Andreikènaitè, 2007). Mixtures of oil, alkylphenols and different PAHs (the composition of which is similar to that of PAHs mixture entering the Sea with produced water) were genotoxic and cytotoxic to turbot and Atlantic cod. These studies revealed that there are species-specific and tissue-specific differences of response to the action of oil components (Baršienè et al., 2006a). Induction of bi-nucleated cells was observed in erythrocytes of peripheral blood and cephalic kidney erythrocytes of turbot (Scophthalmus maximus) treated with crude oil and with nonylphenol. Elevation of immature erythrocytes with nuclear buds was noted after the exposure to crude oil. Fragmented-apoptotic cells appeared after the exposure to nonylphenol and to spiked oil (Baršiene et al., 2006a). Increased level of genotoxic effects in different fish species were observed after the „Haven“ oil spill in the Ligurians Sea (Pietrapiana et al., 2002) and after an accidental oil spill in the Baltic Sea (Baršienè et al., 2004, 2006b, 2006d). MN formation, changes in EROD, benzo[ $\alpha]$ pyrene monooxygenase and acetylcholine esterase activities, accumulation of naphthalene-type PAH metabolites in the bile was observed in Gambusia affinis effected by produced water (Casini et al., 2006). Genotoxicity of benzo[a]pyrene, as one of the components, has been shown in laboratory experiments (Al-Sabti, 1986; Metcalfe, 1988; Kim and Hyun, 2006; Maria et al., 2002a, 2002b). Time- and dose-dependant formation of $\mathrm{MN}$ in the liver cells of the European sea bass (Dicentrarchus labrax) and the eel (Anguilla anguilla) was observed after treatment with naphthalenes and water-soluble oil fractions (Pacheco and Santos, 2001; Gravato and Santos, 2002; Teles et al., 2003). A time-related induction of micronuclei in juvenile Dicentrarchus labrax liver has been observed after treatment with naphtalenes (Gravato and Santos, 2002).

There are a number of experimental studies which demonstrates, that nuclear abnormalities other than MN are sensitive and informative biomarkers (Pacheco and Santos, 1999; Ayllón and Gracia-Vazquez, 2000, 2001; Ateeq et al., 2002; Çavaș and Ergene-Gözükara, 2003; Baršienè et al., 2006a; Baršienè and Andreikėnaitè, 2007). Mutagenic potential of secondary-treated bleached pulp mill effluents was revealed by laboratory and field experiments performed by Pacheco and Santos (1999). This complex mixture induced dose dependent formation of MN and other nuclear abnormalities in erythrocytes of adult eel. Exposure with colchicine and mitomycin-C induced formation of MN, notched, lobed, blebbed, and vacuolated nuclei in renal erythrocytes of European minnow (Phoxinus phoxinus) and mollie (Poecilia latipinna), whereas intraperitoneal injections cyclophosphamide and cadmium chloride induced formation of the nuclear abnormalities but not 
MN (Ayllón and Gracia-Vazquez, 2000). Intraperitoneal injections of colchicine, acrylamide and $N$-ethyl- $N$-nitrosourea induced formation of $\mathrm{MN}$ but not the other nuclear abnormalities in cephalic kidney erythrocytes of rainbow trout (Oncorhynhus mykiss). In the same study performed by Ayllón and Gracia-Vazquez (2001), cyclophosphamide induced formation of MN and the other nuclear abnormalities, whereas mitomycin-C induced only formation of the nuclear abnormalities. Exposure of Nile tilapia (Oreochromis niloticus) with different concentrations of textile mill effluent and cyclophosphamide induced dose-dependent increase of $\mathrm{MN}$ as well as binuclei, lobed, blebbed and notched nuclei in peripheral blood erythrocytes (Çavaș and Ergene-Gözükara, 2003). Two herbicides, 2,4-dichlorophenoxyacetic acid and butachlor induced dose and time dependant genotoxic and cytotoxic effects in peripheral erythrocytes of catfish (Clarias batrachus) (Ateeq et al., 2002). In eel treatment with $0.3,0.9$ and $2.7 \mu \mathrm{M}$ of naphtalene caused induction of $\mathrm{MN}$ and other nuclear abnormalities (Teles et al., 2003).Elevated frequencies of erythrocytes with MN, lobed and blebbed nuclei were observed in butterfish (Pholis gunnellus) inhabiting contaminated areas of the Firth of Forth, Scotland (Bombail et al., 2001). Increased levels of environmental genotoxicity and cytotoxicity were observed in polluted areas off the southeastern Mediterranean coast of Turkey. The frequencies of $\mathrm{MN}$, binucleated, notched, blebbed and lobed nuclei were significantly higher in peripheral blood erythrocytes and gill cells of the grey mullet (Mugil cephalus) from areas contaminated by different types of industrial effluents and aromatic hydrocarbons, in comparison with relatively unpolluted control area. In this study performed by Çavaş and Ergene-Gözükara (2005a) seasonal variations in MN frequencies were also observed.

The results of the current study revealed higher frequencies of the analyzed abnormalities in dab from the offshore zones of the North Sea in comparison with dab from the Baltic Sea, although the Baltic Sea is considered more polluted than the North Sea. In the surface waters of the Baltic Sea, the concentrations of PAHs were from 2 to 10 times higher than those observed in the North Sea (Witt and Matthaus, 2001). Studies indicate adaptations of marine organisms to a heavily polluted environment (Zorita et al., 2006), as well as genetic differences between populations living in the Baltic and the North Sea (Nielsen et al., 2004; Johannesson and Andre, 2006; Poulsen et al., 2006).

Inter-tissue analysis of MN, NB and FA cells in mature blood and immature cephalic kidney erythrocytes of dab revealed higher values in immature erythrocytes. Kidney of fish is the main organ of hemopoiesis, where cells divide extensively and $\mathrm{MN}$ can arise in the early stages of erythrocyte development. Mature blood erythrocytes are none-proliferate cells and MN cannot appear de novo (Carrasco et al., 1990). MN frequency in kidney erythrocytes reflects the damage caused during cell proliferation, while MN analysis in blood erythrocytes shows the general impact of genotoxins occurring during the period of erythrocyte development and circulation (Schlegel and MacGregor, 1982). Considering inter-tissue differences in the formation of micronuclei in fish, a MN test of kidney immature erythrocytes could be proposed as a more reliable tool for the assessment of environmental genotoxicity.

Data of the present study revealed higher frequencies of $\mathrm{MN}, \mathrm{NB}$ and fragmented-apoptotic cells in the North Sea flatfish females than in males. It should be stressed that higher prevalence of liver tumors has been also described in flounder females from the southeastern part of the North Sea (Wadden Sea) (Köhler, 2004). Moreover, appearance of pre-neoplasms and neoplasms in winter flounder (Pleuronectes americanus) showed positive associations with distribution of (benzo[a]pyrene, benzo[e]pyrene, benzo[a]anthracene, di-benzo[a,h]anthracene, perylene, chrysene, and fluoranthene (Chang et al., 1998). 
Studies of nuclear abnormalities in Atlantic cod (G. morhua) in December 2003 and September 2004 revealed seasonal differences. Frequencies of nuclear abnormalities in winter 2003 were very low, while in autumn of the next year they were 3-10 times higher. Though baseline frequency of MN depends on variety of biotic and abiotic factors (Brunetti et al., 1988), it can be assumed that higher water temperature in the offshore areas of the Baltic and the North Sea affects mitotic activity and $\mathrm{MN}$ formation in fish. Micronuclei are formed during cell division, and the mitotic activity of poikilotherm organisms very largely depends on water temperature (Brunetti et al., 1992).

The results of the study suggest that the analysis of $\mathrm{MN}$ and other nuclear abnormalities in flatfish species can be successfully used in the monitoring and assessment of genotoxicity and cytotoxicity in the marine environment. For an environmental assessment, it is particularly important to define reference levels of biological effects. Based on our results, MN frequency lower than $0.05 \%$ o could be suspected as a reference level in the peripheral blood erythrocytes of flatfish from the Baltic Sea and lower than $0.1 \%$ in the North Sea. The recorded environmental genotoxicity levels in fish from many offshore sampling sites of the Baltic and North Seas, suggests that the biomarker responses can be included in future monitoring programs. Ecologically relevant information on environmental genotoxicity in offshore zones could be obtained by an assessment of MN in blood or in kidney erythrocytes of indigenous species. The results on the induction of fragmented-apoptotic cells in fish from oil industrial zones indicate a reliability of this parameter for the assessment of cytotoxicity in marine environment in situ. The analysis of $\mathrm{MN}$, NB and FA cells in flatfish and Atlantic cod can be considered as a sensitive tool for the assessment of environmental genotoxicity in oil and gas platform zones, areas affected by municipal and industrial pollution.

\section{Acknowledgements}

This work was supported by the European Commission (Research Directorate General, Environment Program-Marine Ecosystems) through the BEEP project "Biological Effects of Environmental Pollution in Marine Coastal Ecosystems" (contract EVK3-CT2000-00025).

\section{References}

Akcha, F., Hubert, F.V., Phol-Leszkowicz, A., 2003. Potential value of the comet assay and DNA adduct measurement in dab (Limanda limanda) for assessment of in situ exposure to genotoxic compounds. Mutation Research 534, 21-32.

Albalat, A., Potrykus, J., Pempkowiak, J., Porte, C., 2002. Assessment of organotin pollution along the Polish coast (Baltic Sea) by using mussels and fish as sentinel organisms. Chemosphere 47, 165-171.

Al-Sabti, K., 1986. Comparative micronucleated erythrocyte cell induction in three cyprinids by five carcinogenic-mutagenic chemicals. Cytobios 47, 147-154.

Al-Sabti, K., Hardig, J., 1990. Micronucleus test in fish from monitoring the genotoxic effects of industrial waste products in the Baltic Sea, Sweden. Compar. Biochem. And Physiol. Part C: Comparative Pharmacology 97(1), 179-182.

Al-Sabti, K., Franko, M., Andrijani, B., Knez, S., Stegnar, P. 1994. Chromium induced micronuclei in fish. Journal of Applied Toxicology 14, 333-336.

Al-Sabti, K., Metcalfe, C.D., 1995. Fish micronuclei for assessing genotoxicity in water. Mutatational Research 343, 121-135. 
Ateeq, B., Abul farah, M., Niamat, A.M., Ahmad, W., 2002. Induction of micronuclei and erythrocyte alterations in the catfish Clarias batrachus by 2,4-dichlorophenoxyacetic acid and butachlor. Mutation Research 518, 135-144.

Ayllón, F., Garcia-Vazquez, E., 2000. Induction of micronuclei and other nuclear abnormalities in European minnow Phoxinus phoxinus and mollie Poecilia latipinna: an assessment of the fish micronucleus test. Mutatation Research 467, 177-186.

Ayllón, F., Garcia-Vazquez, E., 2001. Micronuclei and Other Nuclear Lesions as Genotoxicity Indicators in Rainbow Trout Oncorhynchus mykiss Ecotoxicology and Environmental Safety 49, 221-225.

Baršienè, J., 1980. Mechanism of populational and ontogenetical variability of chromosome sets in Atlantic salmon Salmo salar L. In: Karyological polymorphism and mutagenesis in fish. Ed. by V.S Kirpitchnikov, Leningrad, Science 3-9 (in Russian).

Baršienė, J., Baršytė Lovejoy, D., 2000. Environmental genotoxicity in Klaipeda port area. International Review of Hydrobiology 85, 663-672.

Baršienė, J., Lazutka, J., Šyvokienė, J., Dedonytė, V., Rybakovas, A., Bjornstad, A., Andersen, O.K., 2004. Analysis of micronuclei in blue mussels and fish from the Baltic and the North Seas. Environmental Toxicology 19, 365-371.

Baršienè, J., Dedonytè, V., Rybakovas, A., Andreikènaite, L., Andersen, O.K., 2005. Induction of micronuclei in Atlantic cod (Gadus morhua) and turbot (Scophthalmus maximus) after treatment with bisphenol A, diallyl phthalate and tetrabromodiphenyl ether-47. Ekologija 4, 1-7.

Baršienė, J., Dedonytė, V., Rybakovas, A., Andreikènaitė, L., Andersen, O.K., $2006 a$. Investigation of micronuclei and other nuclear abnormalities in peripheral blood and kidney of marine fish treated with crude oil. Aquatic Toxicology 78S, S99-S104.

Baršienė, J., Lehtonen, K.K., Koehler, A., Broeg, K., Vuorinen, P.J., Lang, T., Pempkowiak, J., Šyvokienė, J., Dedonyte, V., Rybakovas, A., Repečka, R., Vuontisjärvi, H., Kopecka, J., $2006 \mathrm{~b}$. Biomarker responses in flounder (Platichthys flesus) and mussel (Mytilus edulis) in the KlaipèdaBūtingè area (Baltic Sea). Marine Pollution Bulletin 53, 422-436.

Baršienè, J., Andreikènaitè, L., Rybakovas, A., 2006c. Cytogenetic damage in perch (Perca fluviatilis L.) and duck mussel (Anodonta anatina L.) exposed to crude oil. Ekologija 1, 25-31.

Baršienė, J., Schiedek, D., Rybakovas, A., Šyvokienè, J., Kopecka, J., Förlin, L., 2006 d. Cytogenetic and cytotoxic effects in gill cells of the blue mussel Mytilus spp. from different zones of the Baltic Sea. Marine Pollution Bulletin 53, 469-478.

Baršienè, J., Andreikènaite, L., 2007. Induction of micronuclei and other nuclear abnormalities in blue mussels exposed to crude oil from the North Sea. Ekologija, 53, 9-16.

Boller, K., Schmid, W., 1970. Chemische Mutagenese beim Sauger. Das Knochermark des Chinesischen Hamsters als in vivo-test system. Haema- tologische Befunde nach Behandlung mit Trenimon. Humangenetik 11, 35-54.

Bolognesi, C., Rabboni, R., Roggieri, P., 1996. Genotoxicity biomarkers in $M$. galloprovincialis as indicators of marine pollutants. Comparative Biochemistry and Physiology 113(2), 319-323.

Bolognesi, C., Perrone, E., Roggieri, P., Sciutto, A., 2006a. Bioindicators in monitoring long term genotoxic impact of oil spill: Haven case study. Marine Environmental Research 62, 287-291.

Bolognesi, C., Perrone, E., Roggieri, P., Pampanin, D.M., Sciutto, A., 2006b. Assessment of micronuclei induction in peripheral erythrocytes of fish exposed to xenobiotics under controlled conditions. Aquatic Toxicology 78, S93-S98. 
Bombail, W., Aw, D., Gordon, E., Batty, J., 2001. Application of comet and micronucleus assays to butterfish (Pholis gunnellus) erythrocytes from the Firth of Forth, Scotland. Chemosphere 44, 383-392.

Bresler, V., Bissinger, V., Abelson, A., Dizer, H., Sturm, A., Kratke, R., Fishelson, L., Hansen, P.D., 1999. Marine mollusks and fish as biomarkers of Red Sea, Mediterranean Sea and North Sea. Helgoland Marine Research 53, 219-243.

Broeg, K., Lehtonen, K.K., 2006. Indices for the assessment of environmental pollution of the Baltic Sea coasts: Integrated assessment of a multi-biomarker approach. Marine Pollution Bulletin 53, 145-159.

Brunetti, R., Majone, F., Gola I., Beltrame C., 1988. The micronucleus test: examples of application to marine ecology. Marine Ecology Progress Series 44, 65-68.

Brunetti, R., Gabriele, M., Valerio, P., Fumagalli, O., 1992. The micronucleus test: temporal pattern of the baseline frequency in Mytilus galloprovincialis Lmk. Marine Ecology Progress Series $\underline{83,75-78 .}$

Carrasco, K.R., Tilbury, K.L., Myers, M.S., 1990. Assessment of the piscine micronucleus test as an in situ biological indicator of chemical contaminant effects. Canadian Journal of Fisheries and Aquatic Sciences 47, 2123-2136.

Casini, S., Marsili, L., Fossi, M.C., Mori, G., Bucalossi, D., Porcelloni, S., Caliani, I., Stefanini, G., Ferraro, M., di Catenaja, C.A., 2006. Use of biomarkers to investigate toxicological effects of produced water treated with conventional and innovative methods. Marine Environmental Research 62, S347-S351.

Çavaş, T., Ergene-Gozukara, S., 2003. Micronuclei, nuclear lesions and interphase silver stained nucleolar organizer regions (AgNORs) as cyto-genotoxicity indicators in Oreochromis niloticus exposed to textile mill effluent. Mutation Research 538, 81-91.

Çavaş, T., Ergene-Gozukara, S. 2005a. Micronucleus Test in Fish Cells: A Bioassay for In Situ Monitoring of Genotoxic Pollution in the Marine Environment. Environmental and Molecular Mutagenesis 46, 64-70.

Çavaş, T., Ergene-Gözükara, S., 2005b. Induction of micronuclei and nuclear abnormalities in Oreochromis niloticus following exposure to petroleum refinery and chromium processing plant effluents. Aquatic Toxicology 74, 264-271.

Chang, S., Zdanowicz, V.S., Murchelano, R.A., 1998. Associations between liver lesions in winter flounder (Pleuronectes americanus) and sediment chemical contaminants from north-east United States estuaries. ICES Journal of Marine Sciences 55, 954-969.

Depledge, M.H., Fossi, M.C., 1994. The role of biomarkers in environmental assessment (2). Invertebrates. Ecotoxicology 3, 161-172.

Dixon, D.R., Wilson, J.T., Pascoe, P.L., Parry, J.M., 1999. Anaphase aberrations in the embryos of marine tubeworm Pomatoceros lamarckii (Polychaeta: Serpulidae): a new in vivo test assay for detecting aneugens and clastogens in the marine environment. Mutagenesis 14, 375-383.

Dolcetti, L., Venier, P., 2002. Susceptability to genetic damage and cell types in Mediterranean mussels. Marine Environmental Research 54, 487-491.

Falandysz, J., Brzostowski, A., Szpunar, J., Rodriguez-Pereiro, I., 2002. Butyltins in sediments and three-spined stickleback (Gasterosteus aculleatus) from the marinas of the Gulf of Gdansk, Baltic Sea. Journal of Environmental Science and Health, Part A: Toxic/Hazardous Substances and Environmental Engineering A 37, 353-363.

Fenech, M., 2000. The in vitro micronucleus thechnique. Mutation Research 455, 81-95. 
Fenech, M., Chang, W.P., Kirsch-Volders, M., Holland, N., Bonassi, S., Zeiger, E., 2003. HUMN project: detailed description of the scoring criteria for the cytokinesis-block micronucleus assay using isolated human lymphocyte cultures. Mutation Research 534, 65-75.

Ferraro, M.V.M., Fenocchio, A.S., Mantovani, M.S., de Oliveira Ribeiro, C., Cestari, M.M., 2004. Mutagenic effects of tributyltin and inorganic lead (P BII) on the fish H. malabaricus as evaluated using the comet assay and the piscine micronucleus and chromosome aberration tests. Genetics and Molecular Biology 27, 103-107.

Frenzilli, G., Scarcelli, V., Barga, I.D., Nigro, M., Forlin, L., Bolognesi, C., Sturve, J., 2004. DNA damage in eelpout (Zoarces viviparus) from Goteborg harbour. Mutation Research 552, $187-$ 195.

Galassi, S., Bettinetti, R., Neri, M.C., Jeannot, R., Dagnac, T., Bristeau, S., Sakkas, V., Albanis, T., Boti, V., Valsamaki, T., Falandysz, J., Schulte-Oehlmann, U., 2008. A multispecies approach for monitoring persistent toxic substances in the Gulf of Gdansk (Baltic sea). Ecotoxicology and Environmental Safety 69, 39-48.

Gravato, C., Santos, M.A., 2002. Juvenile sea bass liver P450, EROD induction, and erythrocytic genotoxic responses to $\mathrm{PAH}$ and PAH-like compounds. Ecotoxicology and Environmental Safety 51, 115-127.

Gravato, C., Santos, M.A., 2003. Genotoxicity biomarkers' association with B(a)P biotransformation in Dicentrarchus labrax L. Ecotoxicology and Environmental Safety 55, 352358.

Haaf, T., Raderschall, E., Reddy, G., Ward, D.C., Radding, C.M., Golub, E.I., 1999. Sequestration of mammalian Rad51- recombination protein into micronuclei, Journal of Cell Biology 144, 11-20.

Hagger, J.A., Depledge, M.H., Galloway, T.S., 2005. Toxicity of tributyltin in the marine mollusc Mytilus edulis. Marine Pollution Bulletin 51, 8-12.

Hayashi, M., Ueda, T., Uyeno, K., Wada, K., Kinae, N., Saotome, K., Tanaka, N., Takai, A., Sasaki, Y.F., Asano, N., Sofuni, T., Ojima, Y., 1998. Development of genotoxicity assay systems that use aquatic organisms. Mutation Research 399, 125-133.

Heddle, J.A., 1973. A rapid in vivo test for chromosomas damage. Mutation Research 18, 187-190.

Heddle, J.A., Cimino, M.C., Hayashi, M., Romagna, F., Shelby, M.D., Tucker, J.D., Vanparys, Ph., MacGregor, J.T., 1991. Micronuclei as an index of cytogenetic damage: past, present, and future. Environmental and Molecular Mutagenesis 18, 277-291.

HELCOM, 2003. The Baltic Marine environment 1999-2002. In: Baltic Sea Environment Proceedings $87,1-48$.

Jha, A.N., 2004. Review. Genotoxicological studies in aquatic organisms: an overview, Mutation Research 552, 1-17.

Jha, A.N., 2008. Ecotoxicological applications and significance of the comet assay. Mutagenesis 23 (3), 207-221.

Johannesson, K., Andre, C., 2006. Life on the margin: genetic isolation and diversity loss in a peripheral marine ecosystem, the Baltic Sea. Molecular Ecology 15, 2013-2029.

Kannan, K., Senthilkumar, K., Duda, C.A., Villeneuve, D.L., Falandysz, J., Giesy, J., 1999. Butyltin compounds in sediment and fish from the Polish coast of the Baltic Sea. Environmental Science and Pollution Research 6, 200-206. 
Kim, I.-Y., Hyun, C.-K., 2006. Comparative evaluation of the alkaline comet assay with the micronucleus test for genotoxicity monitoring using aquatic organisms. Ecotoxicology and Environmental Safety 64, 288-297.

Köhler, A., 2004. The gender-specific risk to liver toxicity and cancer of flounder (Platichthys flesus (L.)) at the German Wadden Sea coast. Aquatic Toxicology 70, 257-276.

Köhler, A., Ellesat, K., 2008. Nuclear changes in blood, early liver anomalies and hepatocellular cancers in flounder (Platichthys flesus L.) as prognostic indicator for a higher cancer risk? Marine Environmental Research. PRIMO 14, $14^{\text {th }}$ International Symposium Pollutant Responses in Marine Organisms. May, 6-9 2007, Florianopolis/SC, Brazil.

Konat, J., Kowalewska, G., 2001. Polychlorinated biphenyls (PCBs) in sediments of the southern Baltic Sea-trends and fate. The Science of the Total Environment 280, 1-15.

Kopecka, J., Lehtonen, K.K., Baršienè, J., Broeg, K., Vuorinen, P.J., Gercken, J., Pempkowiak, J., 2006. Measurements of biomarker levels in flounder (Platichthys flesus) and blue mussel (Mytilus trossulus) from the Gulf of Gdansk (southern Baltic). Marine Pollution Bulletin 53, 406-421.

Lang, T., Baršienė, J., Broeg, K., Kopecka, J., Parkkonen, J. 2006. Liver histopathology in Baltic flounder (Platichthys flesus) as indicator of biological effects of contaminants. Marine Pollution Bulletin 53, 488-496.

Lehtonen, K.K., Schiedek, D., Köhler, A., Lang, T., Vuorinen, P.J., Förlin, L., Baršienè, J., Pempkowiak, J., Gercke, J., 2006. The BEEP project in the Baltic Sea: Overview of results and outline for a regional biological effects monitoring strategy. Marine Pollution Bulletin 53, 523-537.

Lindberg, H.K., Wang, X., Järventaus, H., Falck, G.C.-M., Norppa, H., Fenech. M. 2007. Origin of nuclear buds and micronuclei in normal and folate-deprived human lymphocytes. Mutation Research 617, 33-45.

Mac Gregor, J.T., 1991. Micronuclei as an index of cytogenetic damage: past, present, and future. Environmental and Molecular Mutagenesis 18, 277-291.

Maria, V.L., Correia, A.C., Santos, M.A., 2002a. Benzo[a]pyrene and b-Naphthoflavone mutagenic activation by European eel (Anquilla anquilla L.) S9 liver fraction. Ecotoxicology and Environmental Safety 53, 81-85.

Maria, V.L., Correia, A.C., Santos, M.A., 2002b. Anquilla anquilla L. biochemical and genotoxic response to benzo[a]pyrene. Ecotoxicology and Environmental Safety 53, 86-92.

Metcalfe, C.D., 1988. Induction of micronuclei and nuclear abnormalities in the erythrocytes of mudminnows (Umbra limi) and brown bullheads (Ictalurus nebulosus). Bulletin Environmental Contamination and Toxicology 40, 489-495.

Mičić, M., Bihari, N., Labura, Ž., Muller, E.G., Batel, R., 2001. Induction of apoptosis in the blue mussel Mytilus galloprovincialis by tri-n-butyltin chloride. Aquatic Toxicology 55, 61-73.

Miele, M., Bonatti, S., Menichini, P., Ottaggio, L., Abbondandolo, A., 1989. The presence of amplified regions affects the stability of chromosomes in drug-resistant Chinese hamster cells. Mutation Research 219, 171-178.

Nielsen, E.E, Nielsen, P.H., Meldrup, D., Hansen, M.M., 2004. Genetic population structure of turbot (Scophthalmus maximus L.) supports the presence of multiple hybrid zones for marine fishes in the transition zone between the Baltic Sea and the North Sea. Molecular Ecology 13, 585595.

OSPAR Commission, 2000. Quality Status Report 2000, Region II - Greater North Sea. OSPAR Commission, London. 136-221. 
Pacheco, M., Santos, M.A., 1999. Biochemical and Genotoxic Responses of Adult Eel (Anguilla anguilla L.) to Resin Acids and Pulp Mill Effluent: Laboratory and Field Experiments. Ecotoxicology and Environmental Safety 42, 81 - 93.

Pacheco, M., Santos, M.A., 2001. Biotransformation, endocrine, and genetic responses of (Anguilla anguilla L) to petroleum distillate products and environmentally contaminated waters. Ecotoxicology and Environmental Safety 49, 64-75.

Pacheco, M., Santos, M.A., 2002. Biotransformation, genotoxic, and histopathological effects of environmental contaminants in European eel (Anquilla anquilla L.). Ecotoxicology and Environmental Safety 53, 331-347.

Palhares, D., Grisolia, C.K. 2002. Comparison between the micronucleus frequencies of kidney and gill erythrocytes in Tilapia fish, following mitomycin $\mathrm{C}$ treatment. General Molecular Biology 25, 281-284.

Pedeutour, F., Suijkerbuijk, R.F., Forus, A., Van Gaal, J., Van de Klundert, W., Coindre, J.M., Nicolo, G., Collin, F., Van Haelst, U., Huffermann, K., Turc-Carel, C. 1994. Complex composition and coamplification of SAS and MDM2 in ring and giant rod marker chromosomes in well-differentiated liposarcoma. Genes Chromosomes Cancer 10, 85-94.

Pietrapiana, D., Modena, M., Guidetti, P., Falugi, C., Vacchi, M., 2002. Evaluating the genotoxic damage and hepatic tissue alterations in demersal fish species: a case study in the Ligurian Sea (NW-Mediterranean). Marine Pollution Bulletin 44, 238-243.

Poulsen, N.A., Nielsen, E.E., Scheirup, M.H., Loeschce, V., Grunkjer, P., 2006. Long-term stability and effective population size in North Sea and Baltic Sea cod (Gadus morhua). Molecular Ecology 15, 321-331.

Rodriguez-Cea, A., Ayllón, F. and Garcia-Vazquez, E. 2003. Micronucleus test in freshwater fish species: an evaluation of its sensitivity for application in field surveys. Ecotoxicology and Environmental Safety 56, $442-448$.

Rosas, I., Carbajal, M.E., Gomez-Arroyos, S., Belmont, R., Villalobos-Pietrini, R., 1984. Cytogenetic effect of cadmium accumulation on water hyacinth Eichornia crassipes. Environmental Research 33, 386-395.

Ruedel, H., Lepper, P., Steinhanses, J., Schroeter-Kermani, C., 2003. Retrospective monitoring of organotin compounds in marine biota from 1985 to 1999: results from the German environmental specimen bank. Environmental Science and Technology 37, 1731-1738.

Schiedek, D., Broeg, K., Baršienė, J., Lehtonen, K.K., Gercken, J., Pfeifer, S., Vuontisjärvi, H., Vuorinen, P.J., Dedonyte, V., Koehler, A., Balk, L., Schneider, R., 2006. Biomarker responses as indication of contaminant effects in blue mussel (Mytilus edulis) and female eelpout (Zoarces viviparus) from the southwestern Baltic Sea. Marine Pollution Bulletin 53, 387-405.

Schlegel, R., MacGregor, J.T., 1982. The persistence of micronuclei in peripheral blood erythrocytes: detection of chronic chromosome breakage in mice. Mutation Research 104, 367369.

Schmid, W., 1975. The micronucleus test. Mutation Research 31, 9-15.

Schnell, S., Schiedek, D., Schneider, R., Balk, L., Vuorinen, P.J., Karvinen, H., Lang, T., 2008. Biological indications of contaminant exposure in Atlantic cod (Gadus morhua) in the Baltic Sea. Canadian Journal of Fisheries and Aquatic Sciences 65, 1122-1134.

Schulz, H.-M., Emeis, K.-C., 2000. Sources and pathways of natural and anthropogenic hydrocarbons into the natural dump. Environmental Geology 39, 839-848. 
Shimizu, N., Itoh, N., Utiyama, H., Wahl, G.M., 1998. Selective entrapment of extrachromosomally amplified DNA by nuclear budding and micronucleation during $\mathrm{S}$ phase. Journal of Cell Biology 140, 1307-1320.

Shimizu, N., Shimuara, T., Tanaka, T., 2000. Selective elimination of acentric double minutes from cancer cells through the extrusion of micronuclei. Mutation Research 448, 81-90.

Silberhorn, E.E., Glauert, H.P., Robertson, L.W., 1990. Carcinogenicity of polyhalogenated biphenyls. Critical Reviews in Toxicology 20, 397-426.

Stachnik, M., Wolowicz, M., 2007. The neoplastic disease in Macoma balthica (L.) - an impact on condition of the Baltic clam population from the Gulf of Gdansk (Baltic Sea). World Congress of Malacology Antwerp, Belgium, 15-20 July. Abstracts, 214.

Steinert, S.A., 1996. Contribution of apoptosis to observed DNA damage in mussel cells in polutant responses in marine organisms (PRIMO8). Marine Environmental Research 42, 253-259.

Steinert, S.A., Streib-Montee, R., Sastre, M.P., 1998. Influence of sunlight on DNA damage in mussels exposed to polycyclic aromatic hydrocarbons. Marine Environmental Research 46, 355 358.

Strand, J., Jacobsen, J.A., 2005. Accumulation and trophic transfer of organotins in a marine food web from the Danish coastal waters. Science of The Total Environment 350, 72-85.

Teles, M., Pacheco, M., Santos, M.A., 2003. Anquilla anquilla L liver ethoxyresorufin Odeethylation, glutathione S-transferase, erythrocytic nuclear abnormalities, and endocrine responses to naphthalene and $\beta$-naphthoflavone. Ecotoxicology and Environmental Safety 55, 98-107.

Thiriot-Quiévreux, C., Wolowicz, M., 2001. Chromosomal study of spatial variation of the prevalence of a gill neoplasia in Macoma balthica from the Gulf of Gdansk (Baltic Sea). Ophelia $54,75-81$.

Witt, G., Leipe, T., Emeis, K-C., 2001. Using fluffy layer material to study the fate of particle-bound organic pollutants in the Southern Baltic Sea. Environmental Science and Technology 35, 1567-1573.

Witt, G., Matthaus, W., 2001. The impact of salt water inflows on the distribution of polycyclic aromatic hydrocarbons in the deep water of the Baltic Sea. Marine Chemistry 74, 279301.

Witt, G., 2002. Occurrence and transport of polycyclic aromatic hydrocarbons in the water bodies of the Baltic Sea. Marine Chemistry 79, 49-66.

Yankiwski, V., Marciniak, R.A., Guarente, L., Neff, N.F., 2000. Nuclear structure in normal and Bloom syndrome cells, Proceedings of the National Academy of Sciences U.S.A. 97, 52145219.

Zorita, I., Ortiz-Zarragoitia, M., Soto, M., Cajaraville, M.P., 2006. Biomarkers in mussels from a copper site gradient (Visnes, Norway): An integrated biochemical, histochemical and histological study. Aquatic Toxicology 78S, S109-S116. 


\section{Tables}

Table 1. Brief description, geographical coordinates, sampling depth, water temperature and salinity of the Baltic Sea sampling areas, 258, 267 cruises of RV „Walther Herwig III“"

\begin{tabular}{|c|c|c|c|c|c|c|c|}
\hline \multirow{2}{*}{$\frac{\text { Sampling areas and brief }}{\underline{\text { description }}}$} & \multirow[t]{2}{*}{ Latitude } & \multirow[t]{2}{*}{$\underline{\text { Longitude }}$} & \multirow{2}{*}{$\frac{\frac{\text { Depth of }}{\text { trawling }}}{\text { (m) }}$} & \multicolumn{2}{|c|}{ Temperature $\left({ }^{\circ} \mathrm{C}\right)$} & \multicolumn{2}{|c|}{$\underline{\text { Salinity (\%o) }}$} \\
\hline & & & & 2003.12. & 2004.09 . & 2003.12. & 2004.09 . \\
\hline $\begin{array}{l}\text { BEEP1 Gotland Sea } \\
\text { (comparatively far from } \\
\text { potential sources of } \\
\text { pollution, low intensity } \\
\text { marine transport) }\end{array}$ & $57^{\circ} 24^{\prime} 16 \mathrm{~N}$ & $17^{\circ} 02^{\prime} 16 \mathrm{E}$ & $\underline{2-59.5}$ & $\underline{6-5.95}$ & $=$ & $6.99-6.86$ & $=$ \\
\hline $\begin{array}{l}\text { BEEP3 Lithuanian } \\
\text { territorial waters } \\
\text { (extensive ship traffic) } \\
\end{array}$ & $\underline{55^{\circ} 42^{\prime} 62 \mathrm{~N}}$ & $20^{\circ} 29^{\prime} 24 \mathrm{E}$ & $\underline{2-48.5}$ & $\underline{7.48}$ & & $7.22-7.17$ & $=$ \\
\hline $\begin{array}{l}\text { BEEP4 Close to the Gulf } \\
\text { of Gdansk (extensive ship } \\
\text { traffic, potentially } \\
\text { influenced by the Vistula } \\
\text { River and the Sopot- } \\
\text { Gdynia agglomerate) } \\
\end{array}$ & $\underline{54^{\circ} 50^{\prime} 70 \mathrm{~N}}$ & $18^{\circ} 40^{\prime} 95 \mathrm{E}$ & $2-72$ & $\underline{6.55-6.63}$ & $=$ & $7.13-6.28$ & $=$ \\
\hline $\begin{array}{l}\text { BEEP5 Mecklenburg } \\
\text { Bight (extensive ship } \\
\text { traffic and water masses } \\
\text { and pollutant exchange } \\
\text { between the Baltic and } \\
\text { North Seas) } \\
\end{array}$ & $\underline{54^{\circ} 13^{\prime} 42 \mathrm{~N}}$ & $\underline{11^{\circ} 42^{\prime} 53 \mathrm{E}}$ & $\underline{1-24}$ & $\underline{6.62-7.91}$ & $=$ & $16.44-17.62$ & $=$ \\
\hline $\begin{array}{l}\text { B01 Close to Kiel Harbor } \\
\text { and Kiel Canal (very } \\
\text { extensive ship traffic) }\end{array}$ & $\underline{54^{\circ} 34^{\prime} 72 \mathrm{~N}}$ & $10^{\circ} 24^{\prime} 10 \mathrm{E}$ & $3-17$ & $6.39-6.4$ & $=$ & $18.3-18.3$ & $=$ \\
\hline $\begin{array}{l}\text { B03 Bornholm Basin } \\
\text { (comparatively distant } \\
\text { from potential sources of } \\
\text { pollution) }\end{array}$ & $\underline{54^{\circ} 37^{\prime} 84 \mathrm{~N}}$ & $15^{\circ} 03^{\prime} 52 \mathrm{E}$ & $\underline{2-59}$ & $\underline{7.15-9}$ & $\underline{16.24-7.31}$ & $\underline{7.5-6.77}$ & $7.68-14.44$ \\
\hline $\begin{array}{l}\text { B05 Gotland Sea } \\
\text { (comparatively distant } \\
\text { from potential sources of } \\
\text { pollution) }\end{array}$ & $\underline{55^{\circ} 05^{\prime} 30 \mathrm{~N}}$ & $16^{\circ} 32^{\prime} 24 \mathrm{E}$ & $\underline{3-43}$ & $\underline{7.15-9.71}$ & $=$ & $7.47-9.9$ & $=$ \\
\hline $\begin{array}{l}\text { B09 Gotland Sea } \\
\text { (comparatively distant } \\
\text { from potential sources of } \\
\text { pollution) }\end{array}$ & $\underline{55^{\circ} 11 ' 52 \mathrm{~N}}$ & $\underline{18^{\circ} 12^{\prime} 31 \mathrm{E}}$ & $\underline{3-78}$ & $\underline{6.82-7.77}$ & $=$ & $7.17-11.44$ & $=$ \\
\hline $\begin{array}{l}\text { B10 Bornholm Basin } \\
\text { (extensive ship traffic, } \\
\text { influenced by the Oder } \\
\text { River) }\end{array}$ & $\underline{54^{\circ} 40^{\prime} 46 \mathrm{~N}}$ & $14^{\circ} 02^{\prime} 69 \mathrm{E}$ & $3-25$ & $\underline{7.06-7.07}$ & $=$ & $\underline{7.74-7.75}$ & $=$ \\
\hline $\begin{array}{l}\text { B11 Arkona basin (very } \\
\text { extensive ship traffic) }\end{array}$ & $\underline{54^{\circ} 46^{\prime} 91 \mathrm{~N}}$ & $13^{\circ} 11^{\prime} 74 \mathrm{E}$ & $\underline{1-39}$ & $\underline{6.38-6.38}$ & $=$ & $\underline{9.05-12.43}$ & $=$ \\
\hline $\begin{array}{l}\text { B12 Mecklenburg Bight } \\
\text { (very extensive ship } \\
\text { traffic) }\end{array}$ & $\underline{54^{\circ} 22^{\prime} 46 \mathrm{~N}}$ & $11^{\circ} 22^{\prime} 65 \mathrm{E}$ & $\underline{2-22}$ & $=$ & $15.80-15.68$ & $=$ & $13.01-17.21$ \\
\hline $\begin{array}{l}\text { BMP Arkona basin } \\
\text { (extensive ship traffic) } \\
\end{array}$ & $\underline{54^{\circ} 49^{\prime} 61 \mathrm{~N}}$ & $14^{\circ} 06^{\prime} 37 \mathrm{E}$ & $\underline{2-37}$ & $=$ & $14.86-13.59$ & $=$ & $7.68-12.28$ \\
\hline
\end{tabular}


Table 2. Brief description, geographical coordinates, sampling depth, water temperature and salinity of the North Sea sampling areas, 258, 267 cruises of RV „Walther Herwig III“"

\begin{tabular}{|c|c|c|c|c|c|c|c|}
\hline \multirow[t]{2}{*}{$\frac{\text { Sampling areas and brief }}{\text { description }}$} & \multirow[t]{2}{*}{ Latitude } & \multirow[t]{2}{*}{ Longitude } & \multirow{2}{*}{$\frac{\underline{\text { Depth of }}}{\underline{\text { trawling }}}$} & \multicolumn{2}{|c|}{ Temperature $\left({ }^{\circ} \mathrm{C}\right)$} & \multicolumn{2}{|c|}{ Salinity (\%o) } \\
\hline & & & & 2003.12 . & 2004.09 . & 2003.12 & 2004.09 . \\
\hline $\begin{array}{l}\text { N11 Danish off shore } \\
\text { area (potentially } \\
\text { influenced by pollution } \\
\text { from Denmark) }\end{array}$ & $55^{\circ} 30^{\prime} 77 \mathrm{~N}$ & $07^{\circ} 07^{\prime} 95 \mathrm{E}$ & $2-30$ & $=$ & 16.86 & & $\frac{33.98-}{33.99}$ \\
\hline $\begin{array}{l}\text { JMP German Bight } \\
\text { (very extensive ship } \\
\text { traffic, potentially } \\
\text { influenced by the River } \\
\text { Elbe, Hamburg marine } \\
\text { port) }\end{array}$ & $54^{\circ} 20^{\circ} 43 \mathrm{~N}$ & $\underline{07^{\circ} 29^{\prime} 15 \mathrm{E}}$ & $2-28$ & $=$ & $\underline{16.88-16.90}$ & & $\frac{33.26-}{33.34}$ \\
\hline $\begin{array}{l}\text { N01 German Bight (very } \\
\text { extensive ship traffic) }\end{array}$ & $54^{\circ} 22^{\prime} 22 \mathrm{~N}$ & $07^{\circ} 33^{\prime} 42 \mathrm{E}$ & $3-20.5$ & $7.85-7.85$ & & $\frac{33.43-}{33.23}$ & $=$ \\
\hline $\begin{array}{l}\text { N03 Dutch off shore area } \\
\text { (very extensive ship } \\
\text { traffic, potentially } \\
\text { influenced by pollution } \\
\text { from Holland) }\end{array}$ & $53^{\circ} 07^{\prime} 78 \mathrm{~N}$ & $\underline{03^{\circ} 54^{\prime} 73 \mathrm{E}}$ & $2-30$ & & $17.88-17.87$ & $=$ & $\underline{34.77}$ \\
\hline $\begin{array}{l}\text { N06 Firth of Forth } \\
\text { (extensive ship traffic, in } \\
\text { some degree pollution } \\
\text { from Edinburgh region) }\end{array}$ & $56^{\circ} 22^{\prime} 32 \mathrm{~N}$ & $02^{\circ} 01^{\prime} 25 \mathrm{~W}$ & $3-49$ & $9.3-9.4$ & & $\underline{34.73-}$ & \\
\hline $\begin{array}{l}\text { N07 Scottish off shore } \\
\text { area (extensive ship } \\
\text { traffic) }\end{array}$ & $\underline{57^{\circ} 46^{\prime} 35 \mathrm{~N}}$ & $\underline{01^{\circ} 18^{\prime} 55 \mathrm{~W}}$ & $\underline{2-105}$ & $=$ & $\underline{13.60-10.22}$ & $=$ & $35.13-35.27$ \\
\hline $\begin{array}{l}\text { N22 Off shore area } \\
\text { comparatively distant } \\
\text { from potential sources of } \\
\text { pollution }\end{array}$ & $53^{\circ} 38^{\prime} 03 \mathrm{~N}$ & $01^{\circ} 45^{\prime} 01 \mathrm{E}$ & $2-23$ & $=$ & $\underline{16.02-15.79}$ & $=$ & $34.44-34.61$ \\
\hline $\begin{array}{l}\text { N15 Great Fisher Bank } \\
\text { (comparatively distant } \\
\text { from potential sources of } \\
\text { pollution) }\end{array}$ & $57^{\circ} 14^{\prime} 74 \mathrm{~N}$ & $04^{\circ} 01^{\prime} 66 \mathrm{E}$ & $2-62$ & $=$ & $\underline{15.54-8.24}$ & $=$ & $34.57-35.18$ \\
\hline $\begin{array}{l}\text { P02/43 } \\
\text { P02/44 } \\
\text { P02/45 } \\
\text { Ekofisk area (offshore oil } \\
\text { drilling zones) }\end{array}$ & $\frac{\frac{56^{\circ} 47^{\prime} 07 \mathrm{~N}}{56^{\circ} 40^{\prime} 28 \mathrm{~N}}}{\underline{56^{\circ} 31^{\prime} 22 \mathrm{~N}}}$ & $\begin{array}{l}\underline{03^{\circ} 41^{\prime} 98 \mathrm{E}} \\
\underline{03^{\circ} 11^{\prime} 96 \mathrm{E}} \\
03^{\circ} 18^{\prime} 90 \mathrm{E}\end{array}$ & $2-68$ & $=$ & $\underline{16.08-7.81}$ & $=$ & $34.88-35.01$ \\
\hline $\begin{array}{l}\frac{\text { P01/46 }}{\text { P01/48 }} \\
\text { Ekofisk area (offshore oil } \\
\text { drilling zones) }\end{array}$ & $\frac{55^{\circ} 47^{\prime} 15 \mathrm{~N}}{55^{\circ} 40^{\prime} 08 \mathrm{~N}}$ & $\begin{array}{l}\frac{04^{\circ} 47^{\prime} 63 \mathrm{E}}{04^{\circ} 55^{\prime} 05 \mathrm{E}} \\
\end{array}$ & $2-52$ & $\underline{8.8-8.8}$ & $15.92-10.65$ & $34.87-34$ & $34.77-34.74$ \\
\hline $\begin{array}{l}\text { N04 Dogger Bank (gas } \\
\text { extraction area) }\end{array}$ & $\underline{54^{\circ} 48^{\prime} 00 \mathrm{~N}}$ & $\underline{02^{\circ} 09^{\prime} 10 \mathrm{E}}$ & $2-20$ & $=$ & $\underline{16.60-16.33}$ & $=$ & $\underline{34.88}$ \\
\hline
\end{tabular}


Table 3. Number of organisms collected during each cruise in the different sampling areas of the Baltic and the North Seas

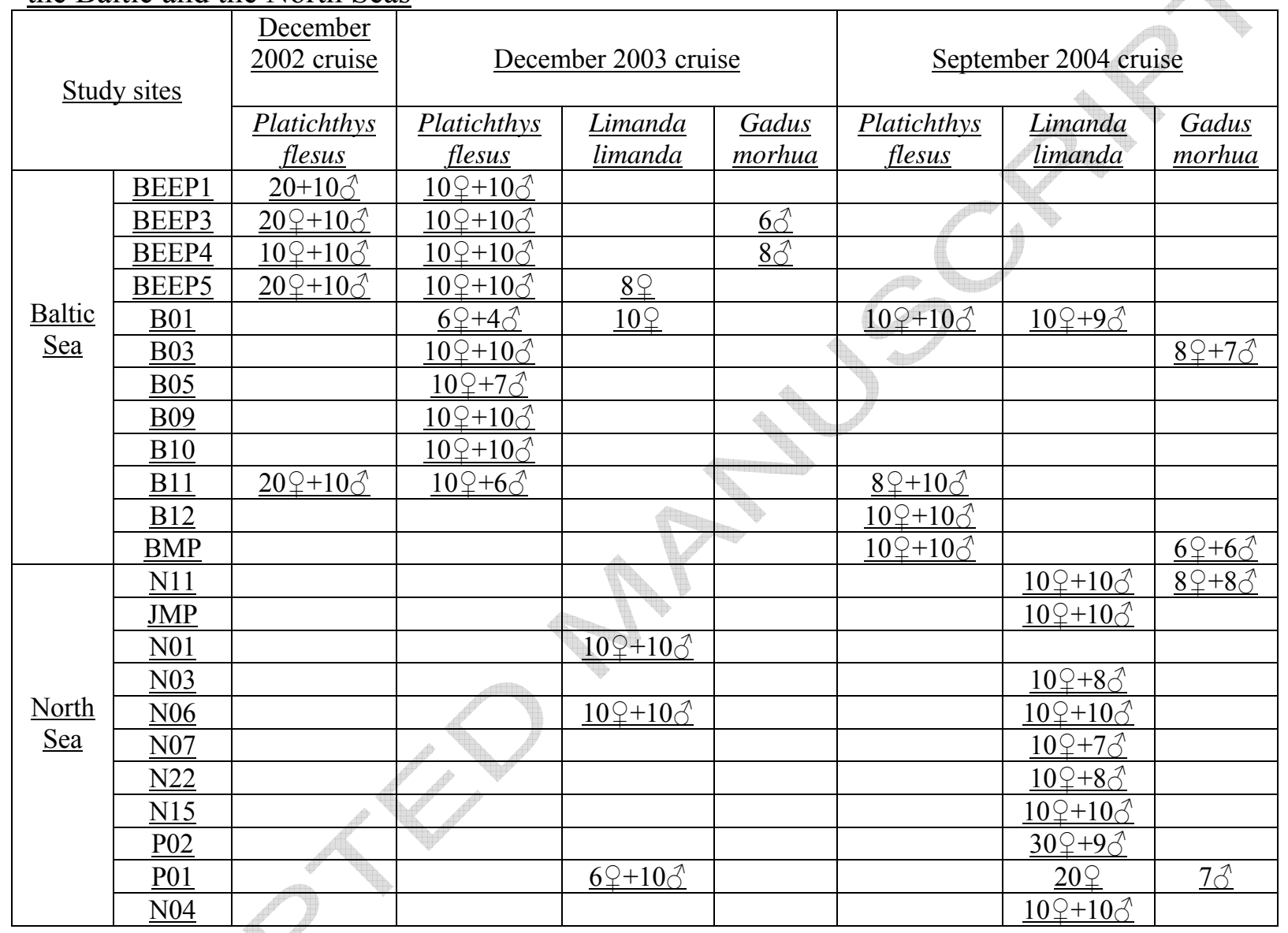




\section{Figure captions}

Fig. 1. Location of sampling areas in the Baltic and North Sea offshore zones.

Fig. 2. Nuclear abnormalities in mature (peripheral blood) and immature (cephalic kidney) fish erythrocytes: (a) micronucleus in dab blood erythrocyte, (b) two micronuclei in flounder blood erythrocyte, (c) nuclear bud in flounder blood erythrocyte, (d) fragmented-apoptotic erythrocyte in cod kidney, x1000.

Fig. 3. Frequencies of micronuclei, nuclear buds and fragmented-apoptotic erythrocytes (mean and standard error) in peripheral blood of flounder ( $P$. flesus) from sampling areas in the Baltic Sea, December 2002, 2003 and September 2004.

Fig. 4. Frequencies of micronuclei, nuclear buds and fragmented-apoptotic cells in mature peripheral blood and immature cephalic kidney erythrocytes of flounder ( $P$. flesus) from sampling areas in the Baltic Sea, September 2004.

Fig. 5. Frequencies of micronuclei, nuclear buds and fragmented-apoptotic erythrocytes (mean and standard error) in peripheral blood of dab (L. limanda) from sampling areas in the North and the Baltic Seas, December 2003 and September 2004.

Fig. 6. Frequencies of micronuclei, nuclear buds and fragmented-apoptotic cells in mature peripheral blood and immature cephalic kidney erythrocytes of dab (L. limanda) from sampling areas in the North and the Baltic Seas, September 2004.

Fig. 7. Frequencies of micronuclei, nuclear buds and fragmented-apoptotic erythrocytes (mean and standard error) in peripheral blood of Atlantic cod (Gadus morhua) from sampling areas in the Baltic and the North Seas, December 2003 and September 2004. 


\section{ACCEPTED MANUSCRIPT}

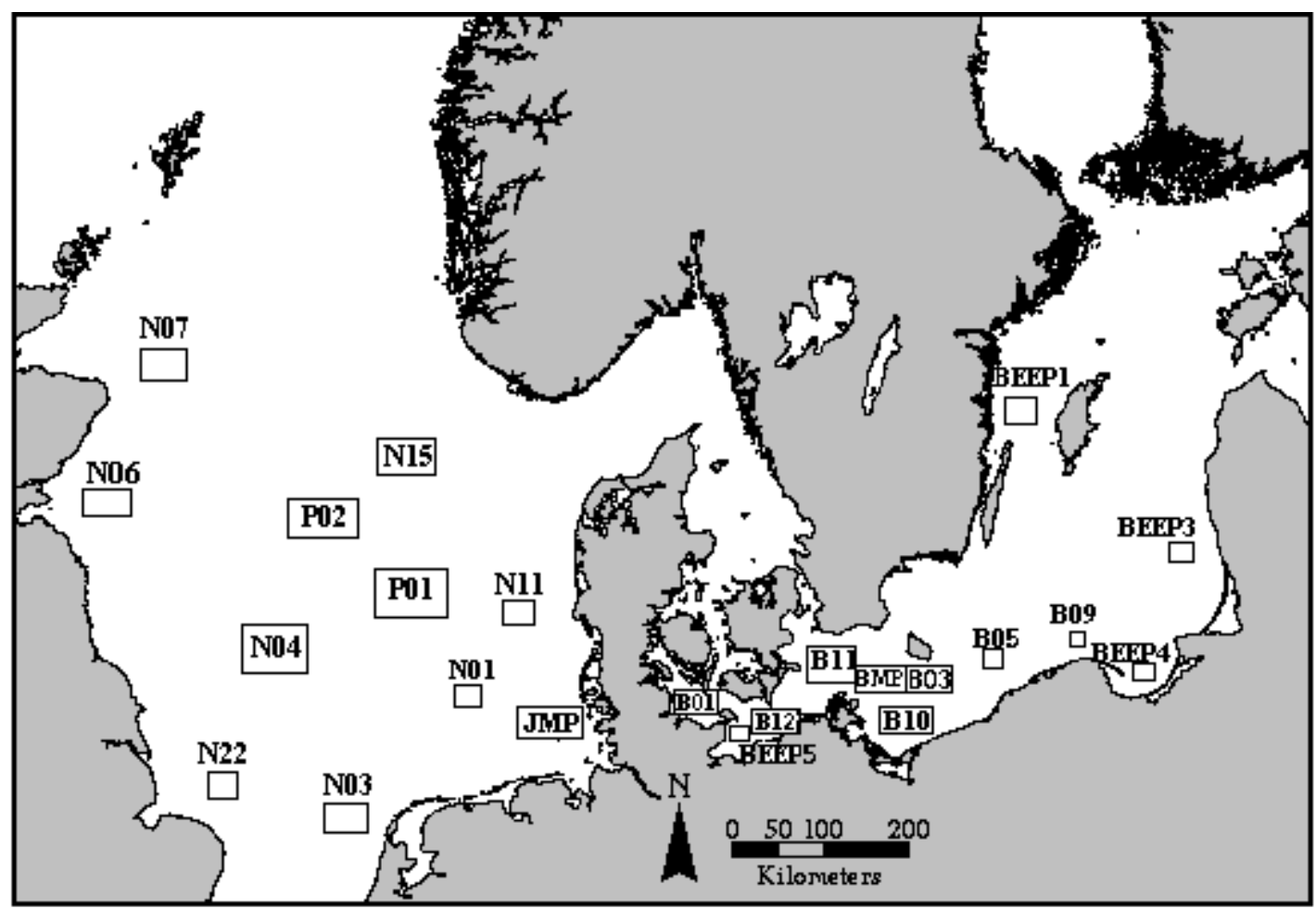






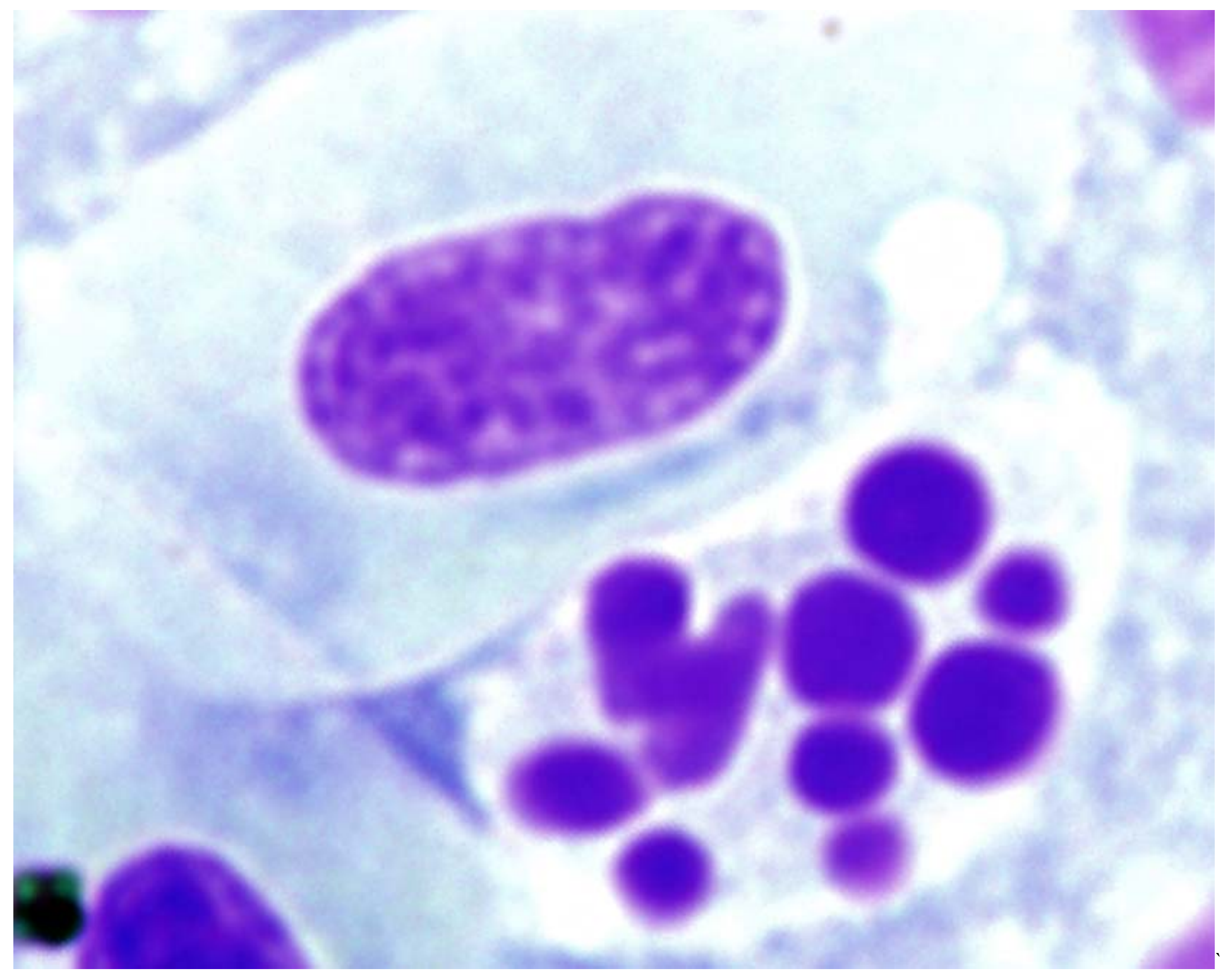




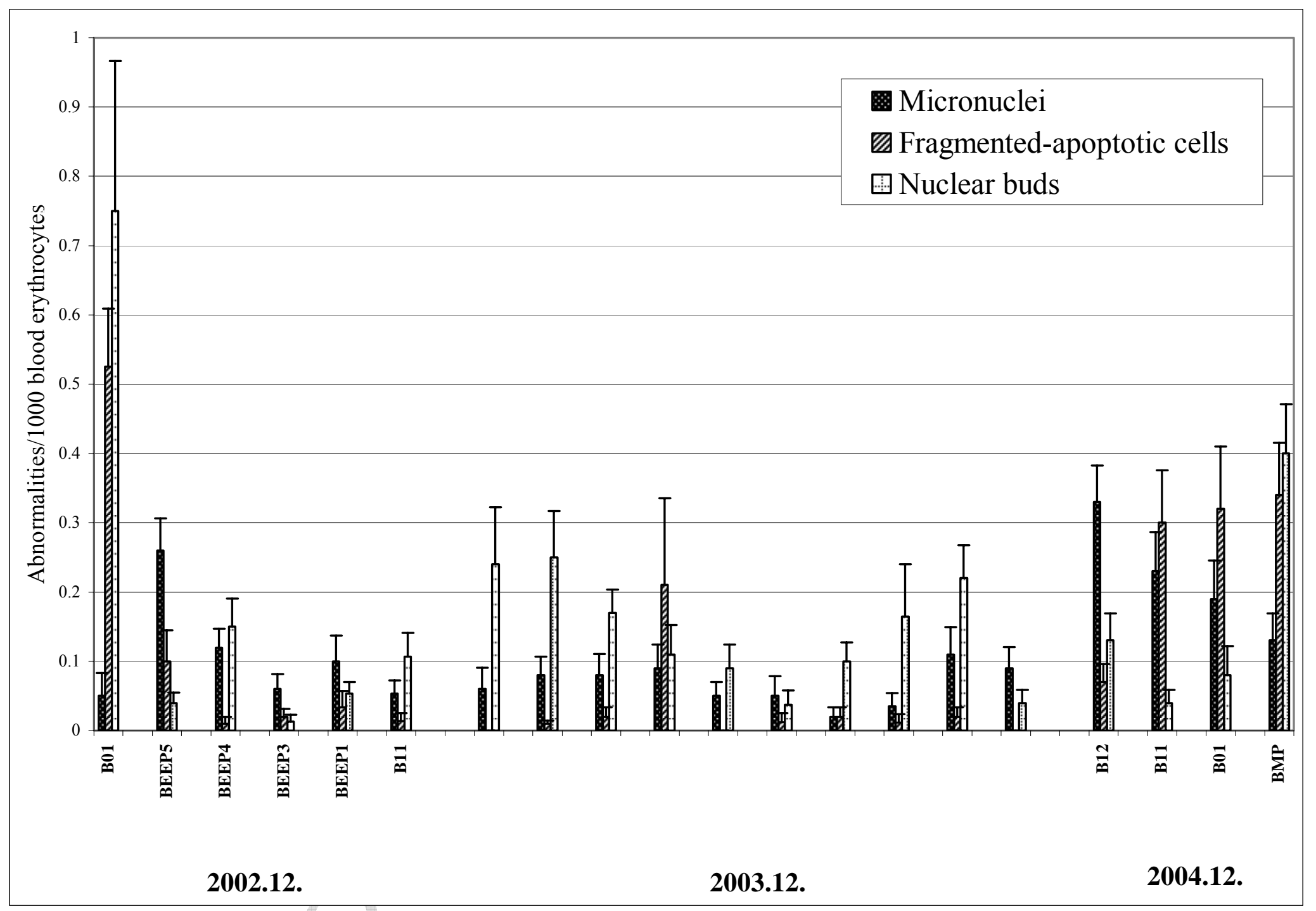




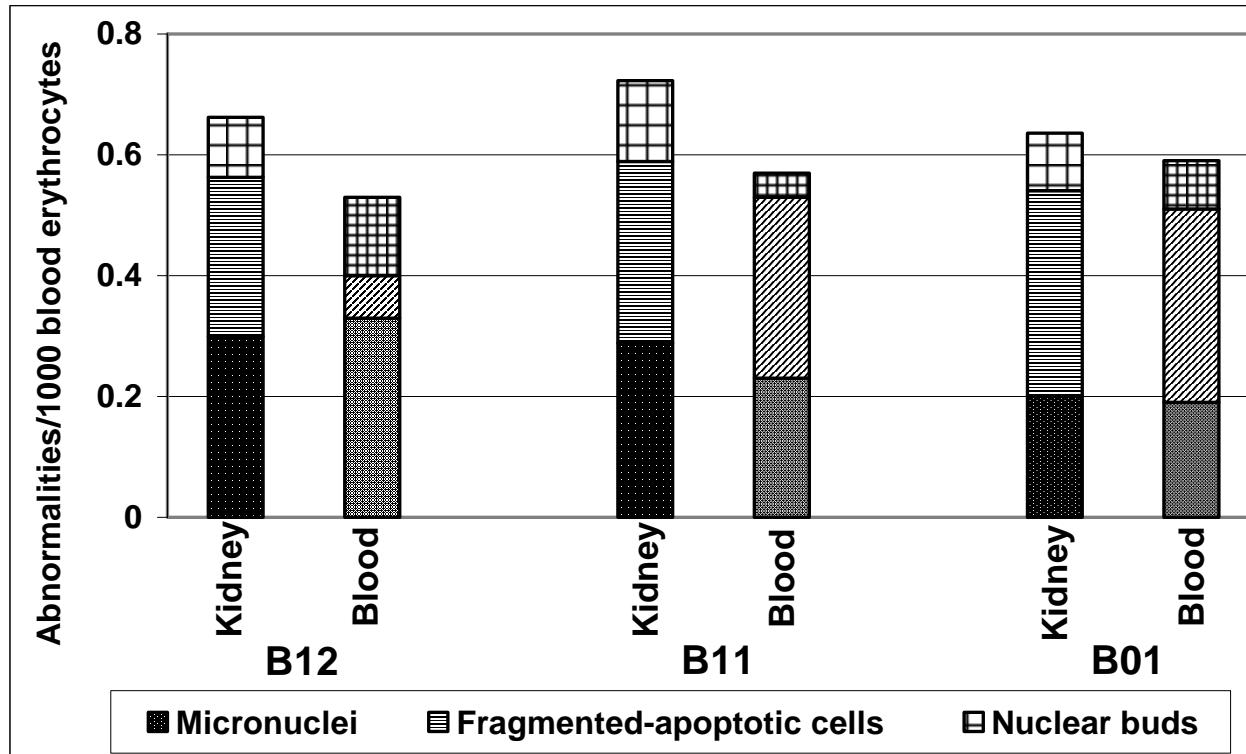




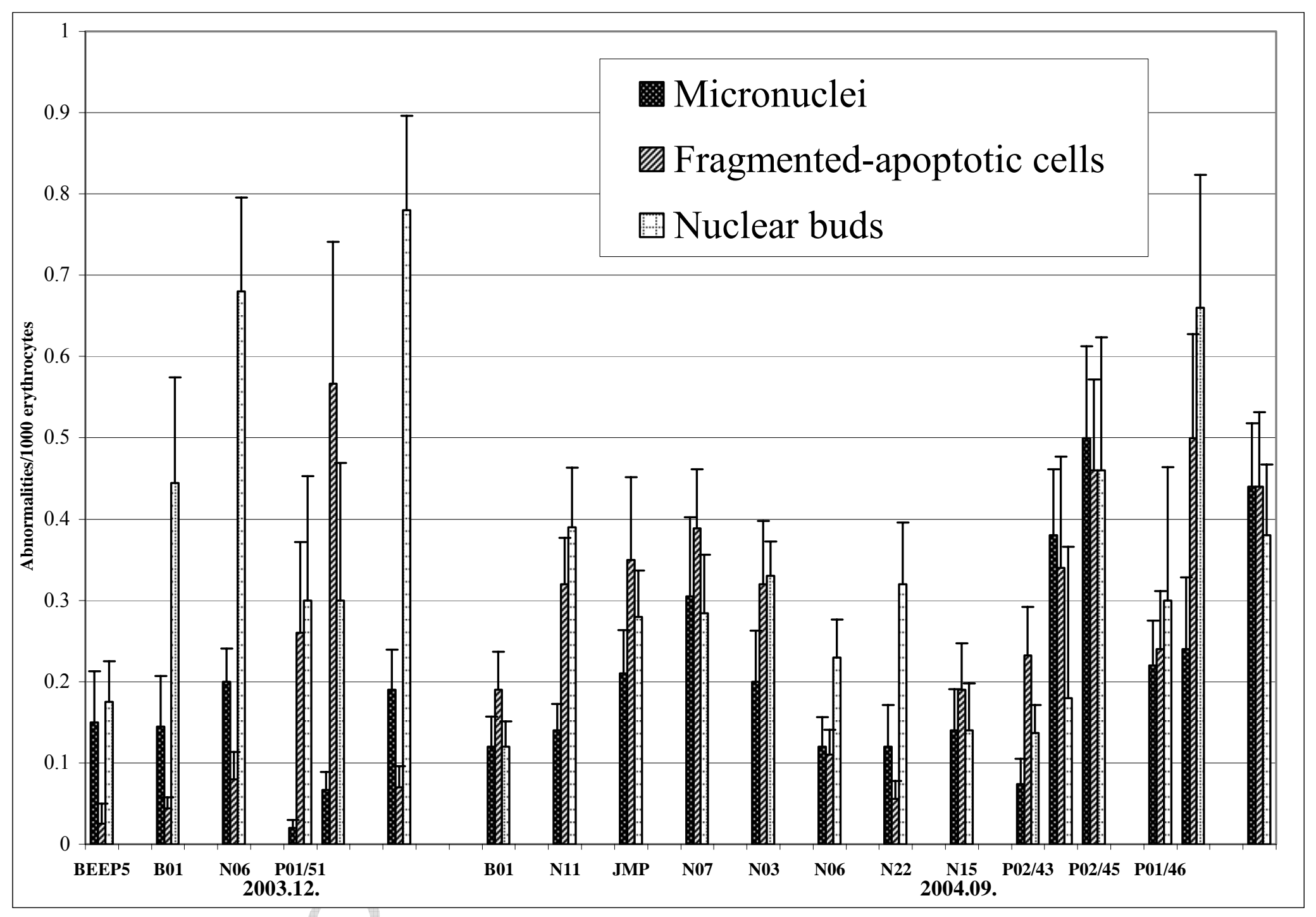




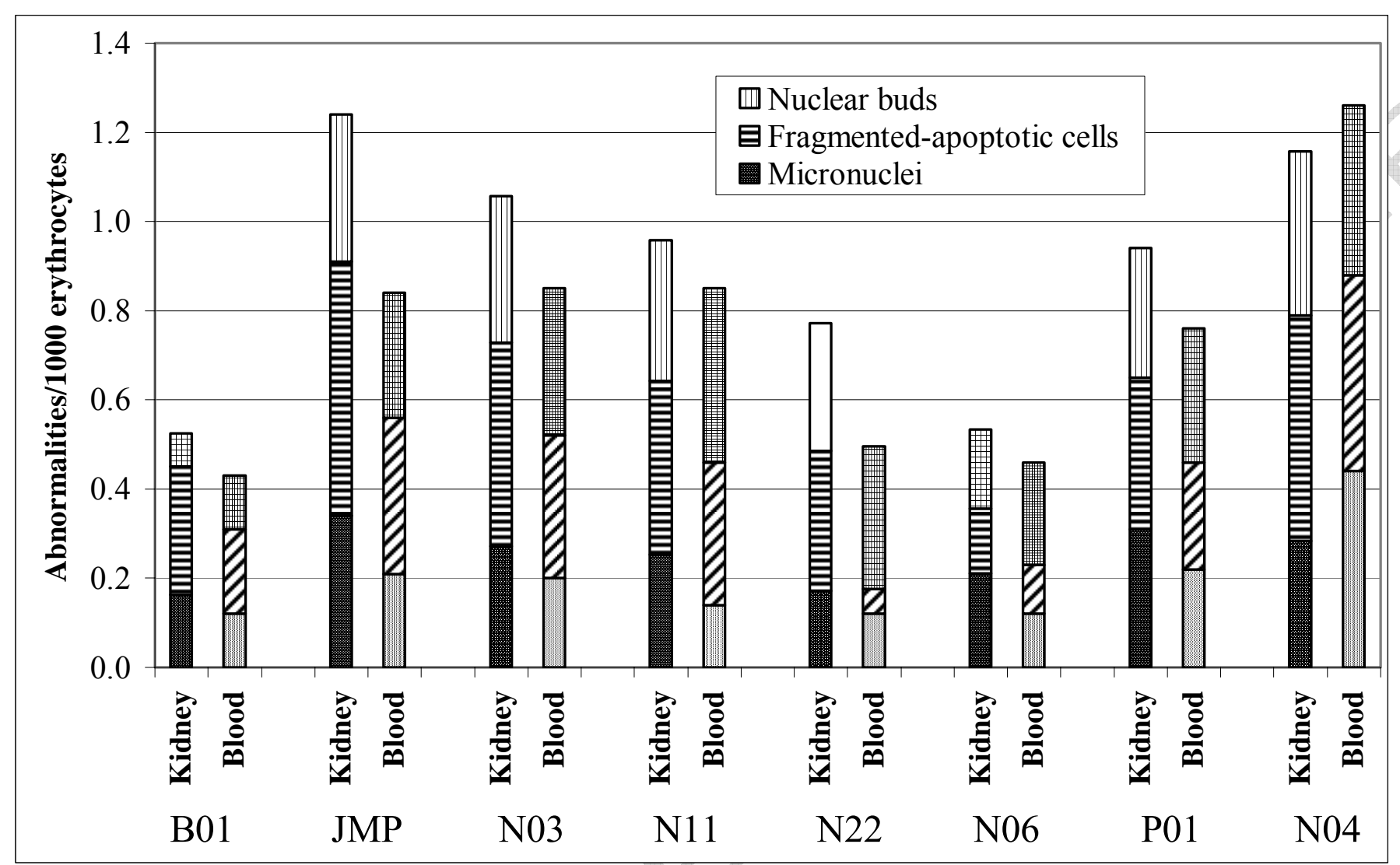




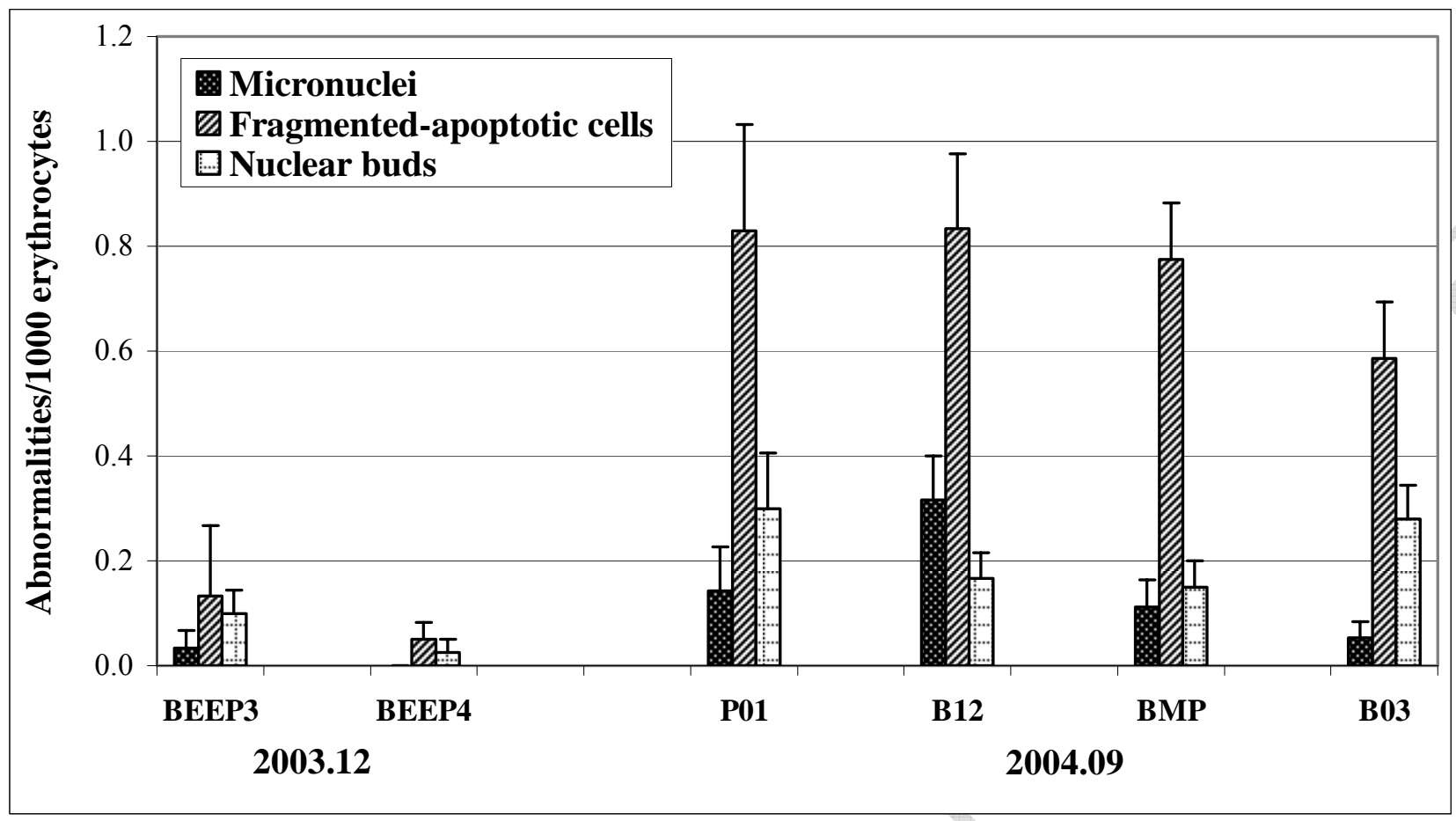

